\title{
INNOVATION AND JOB CREATION AND DESTRUCTION
}

\author{
Evidence from Spain \\ César Alonso-Borrego et Dolores Collado
}

\section{De Boeck Supérieur | Recherches économiques de Louvain}

\author{
2002/1 - Vol. 68 \\ pages 148 à 168
}

\section{ISSN 0770-4518}

Article disponible en ligne à l'adresse:

http://www.cairn.info/revue-recherches-economiques-de-louvain-2002-1-page-148.htm

Pour citer cet article :

Alonso-Borrego César et Collado Dolores, «Innovation and Job Creation and Destruction » Evidence from Spain, Recherches économiques de Louvain, 2002/1 Vol. 68, p. 148-168. DOI : 10.3917/rel.681.0148

Distribution électronique Cairn.info pour De Boeck Supérieur.

(c) De Boeck Supérieur. Tous droits réservés pour tous pays.

La reproduction ou représentation de cet article, notamment par photocopie, n'est autorisée que dans les limites des conditions générales d'utilisation du site ou, le cas échéant, des conditions générales de la licence souscrite par votre établissement. Toute autre reproduction ou représentation, en tout ou partie, sous quelque forme et de quelque manière que ce soit, est interdite sauf accord préalable et écrit de l'éditeur, en dehors des cas prévus par la législation en vigueur en France. II est précisé que son stockage dans une base de données est également interdit. 


\title{
Innovation and Job Creation and Destruction : Evidence from Spain
}

\author{
César Alonso-Borrego* \\ Universidad Carlos III de Madrid \\ M. Dolores Collado* \\ Universidad de Alicante
}

\section{$1 \quad$ Introduction}

Technological innovation is believed to be one of the main sources of employment dynamics, particularly in the creation and destruction of jobs. The role of innovation appears to be of particular interest since the 1990s, when a widespread diffusion of information technology (IT) among all the companies in all the economic sectors is taken place, engendering a substantial restructuring of the businesses (Brynjolfsson and Hitt, 2000). As a general-purpose technology, the main value of IT is its ability to enable organizational complementary investments which affect the production process and the organization of business. Particularly, IT has seemed to facilitate complementary organizational changes and process innovations within the firms in the search for a larger efficiency. Visco (2000) emphasizes the increase in firms' R\&D intensity in all the sectors in every country, which has accompanied the diffusion and the increase of efficiency of IT, and Lehr and Lichtenberg (1999) point out that the first use for IT capital was for R\&D and certain back office support services. However, there is not much empirical evidence about the effect of innovation on job creation and destruction. One of the main reasons for the scarcity of applied work on this issue is the lack of appropriate data due to the difficulties of obtaining adequate observed measures of technological innovation at the microeconomic level. Some longitudinal data sets do not have data on innovation at the establishment

* We thank Raouf Boucekkine, José E. Galdón-Sánchez, and an anonymous referee for helpful comments, and Fundación Empresa Pública for providing the raw data. The first author acknowledges research funding from the Spanish DGI, Grant BEC 2000-0170, and the second author acknowledges research funding from the Spanish DGI, Grant PB98-0979 and from the IVIE. 
level, and the use of industry level measures leaves the empirical results subject to bias due to the aggregation of these measures among highly heterogeneous units. This problem is especially acute in the case of innovation variables, since the number of non-innovative firms is significantly large.

Among the exceptions, we should mention Meghir, Ryan and Van Reenen (1996), who use UK firm-level data to estimate Euler equations for employment where the technological and adjustment cost parameters are allowed to vary with technological stock, and Aguirregabiria and AlonsoBorrego (2001), who use Spanish firm-level data to estimate the effect of the introduction of technology on labor input demands using proxies based on R\&D expenditure. However, these contributions have concentrated on net employment changes, rather than in job creation and job destruction. In another line of research, Davis and Haltiwanger (1992) used plant-level longitudinal data for the US to study the factors which determine job creation and job destruction. The contributions in this line for other countries are numerous. We can mention, among others, Konings (1995) and Blanchflower and Burgess (1996) for the UK, Greenan and Guellec (1997) for France, and Dolado and Gómez (1995), Díaz-Moreno and Galdón-Sánchez (2000), and Ruano (2000) for Spain. Although all these contributions exploit longitudinal data, they differ notably in the level of data disaggregation, in the length of the sample period, and in the data coverage. Notwithstanding, the scope of the empirical results is mostly descriptive, typically concerning bivariate correlations, which are usually disaggregated by establishments' characteristics, such as industry or size. With some exceptions, such as Blanchflower and Burgess (1996), there is no multivariate treatment of the determinants of job creation and destruction. Furthermore, although innovation is frequently mentioned as a potential factor affecting job creation and job destruction, the lack of observed measures has prevented further investigation on this issue.

Here we attempt to provide further evidence using observable measures of technological innovation at the firm level. In order to do this, we use longitudinal data of Spanish manufacturing firms between 1990 and 1997 containing detailed information on firms' innovation activity. Our data set contains input and output measures of innovation, as well as information on employment stock, characteristics of the firm such as age and industry classification, and other variables related to the performance of the firm. The econometric specifications that we estimate are purely empirical, so that in line with the previous literature we just capture partial correlations, but not causality relationships, what precludes any further interpretation, which would require a model to justify the parameter estimates.

In our empirical approach, we estimate separate equations for job creation and job destruction so as to allow estimated effects to differ for creation and destruction. Nonetheless, since firms' decisions on hirings and layoffs are non random, we have to take into account endogenous sample selection bias. For this purpose, we use a two step procedure that follows Heckman (1979) except for the fact that the selection correction mechanism 
is an ordered probit with three alternatives: job destruction, inaction, and job creation. To anticipate our main results, we find that, on average, innovative firms create more jobs - and destroy fewer - than non-innovative, and that the degree of technological effort has a strong positive effect on net employment creation.

The rest of the paper is organized as follows. In section 2, we describe the data set and provide descriptive evidence about the process of job creation and job destruction and their relation to the innovation status of firms and other characteristics. In section 3, we evaluate the impact of innovation activity on job creation and job destruction by means of separate reduced form specifications, controlling for potential endogenous sample selection. Finally, section 4 summarizes the main results and concludes.

\section{The data and preliminary evidence}

The data set is an unbalanced panel of Spanish manufacturing firms, recorded in the database Encuesta Sobre Estrategias Empresariales (Survey on Companies' Strategies, after this, ESEE) during the period 1990-1997. This database contains annual information for a large number of Spanish companies whose main activity was manufacturing between 1990 and 1997 . The original sample includes about $70 \%$ of the companies with more than 200 workers and a representative sample of firms with less than 200 employees, and has been designed to accomplish a representative sample of Spanish manufacturing. This data set contains information on labour and capital inputs, investment on physical capital and R\&D, product and process innovations, and patents. Nevertheless, the data do not provide any disaggregated information on the proportion of investment spent on IT.

\begin{tabular}{|c|c|c|}
\hline \multicolumn{3}{|c|}{ Table 1 : Descriptive Statistics } \\
\hline & Mean & St. Dev. \\
\hline Process Innovation & 0.23376 & 0.42325 \\
\hline Technological effort & 0.00919 & 0.03980 \\
\hline Intermediate Inputs & 2655.847 & 9723.485 \\
\hline Employment & 193.3547 & 476.6201 \\
\hline Fixed Capital & 872.4251 & 3032.929 \\
\hline White Collars & 29.67572 & 18.83645 \\
\hline Age & 21.63764 & 20.14084 \\
\hline Expanding Market & 0.27870 & 0.44838 \\
\hline Contracting Market & 0.26941 & 0.44368 \\
\hline
\end{tabular}

The sample we have used in this paper consists of an unbalanced panel of 1,265 non-energy manufacturing firms which report full information in 
the relevant variables for at least four consecutive years, from 1990 to 1997. The employment variable is the number of employees at the end of the year. In table 1, we present the sample means and standard deviations of the main variables.

Following Davis and Haltiwanger (1992), for each firm we define its size at period $t$ as the average employment between periods $t$ and $t-1$, and its growth rate of employment at period $t$ as the ratio between the change in its employment from $t-1$ to $t$ and its size.

$$
g_{i t}=\frac{N_{i t}-N_{i t-1}}{x_{i t}},
$$

where, for the firm $i$ at period $t, N_{i t}$ denotes employment, and $x_{i t}$ size, as defined above. Gross job creation in industry $s$ at year $t$ is the sum of employment gains in year $t$ at expanding firms in that industry and gross job destruction is the sum of employment losses. Job creation and destruction rates $\left(J C_{s t}\right.$ and $\left.J D_{s t}\right)$ are calculated dividing the gross measures by the industry size in that year ${ }^{1}$

$$
\begin{aligned}
J C_{s t} & =\frac{\sum_{i \epsilon s, g_{i t}>0}\left(N_{i t}-N_{i t-1}\right)}{\sum_{i \epsilon s} x_{i t}} \\
J D_{s t} & =\frac{\sum_{i \epsilon s, g_{i t}<0}\left|N_{i t}-N_{i t-1}\right|}{\sum_{i \epsilon s} x_{i t}}
\end{aligned}
$$

The net employment growth rate is the difference between job creation and job destruction

$$
N E T G_{s t}=J C_{s t}-J D_{s t}
$$

Finally, the job reallocation rate is defined as the sum of the job creation and destruction rates

$$
R_{s t}=J C_{s t}+J D_{s t}
$$

Figure 1 shows the frequency distribution of the employment growth rate in our sample. Most of the firms experience a low rate of employment growth; 32 percent of the observations lying on the interval [ $-0.05,0.05]$, and 58 percent on the interval $[-0.1,0.1]$. The proportion of observations with negative employment growth is larger than the proportion of observations with positive employment growth. This is due to the sample period we are using, which mainly corresponds to a recession period.

In figure 2 we present annual job creation, job destruction, net employment growth and job reallocation rates by year and by two-digit industry ${ }^{2}$.

1 Industry size in year $t$ is the average of industry employment in year $t$ and $t-1$.

2 The industries in our sample are : Iron, steel and metal (22); Building materials (24); Chemicals (25); Nonferrous metal (31); Basic machinery (32); Office machinery (33); Electric materials (34); Electronic (35); Motor vehicles (36); Shipbuilding (37); Other motor vehicles (38); Precision instruments (39); Non-elaborated food (41); Food, tobacco and drinks (42); Basic textile (43); Leather (44); Garment (45); Wood and furniture (46); Cellulose and paper edition (47); Plastic materials (48); Other non-basic industries (49). Industries 33, $37,38,39$ and 44 were not included in the figure due to their small number of observations. 


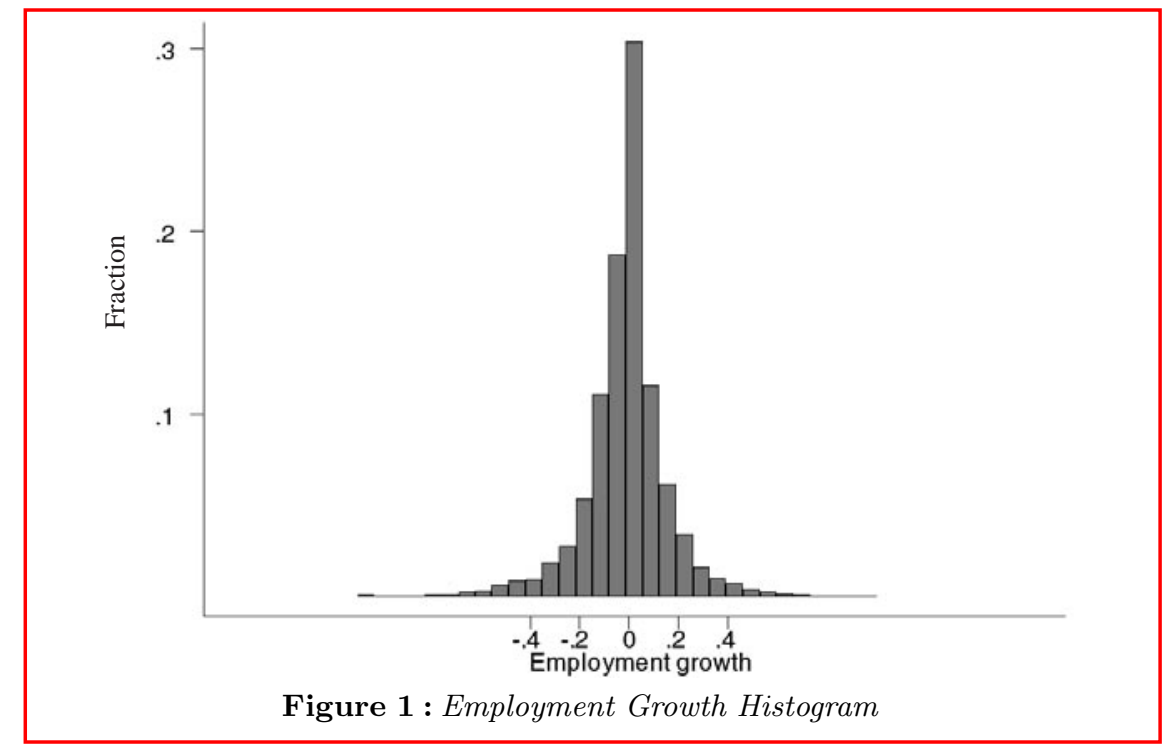

The figures for each year correspond to the whole manufacturing sector, and the net job destruction rates are quite similar to the aggregate figures derived from the Labour Force Survey. At any phase of the business cycle, we observe simultaneously creation and destruction of jobs. Even in deep recessions some firms are increasing their number of employees. Although our sampling period is quite short, we can see that job creation is less volatile than job destruction. As it was expected, the cyclical pattern of both measures is very different. Job destruction rises while job creation tends to fall during recessions. As a consequence, the behavior of net employment growth in manufacturing industries reflects the economic cycle. ${ }^{3}$ This cyclical pattern is similar in other countries (see Davis and Haltiwanger (1998) for a survey on the empirical regularities of job flows found for different countries). Finally, job reallocation exhibits a countercyclical pattern, being higher in recessions than in recovery periods.

The industry figures are weighted averages of the seven annual rates from 1991 to 1997 for each industry, where the weights are industry sizes in each year. In all industries except for plastic materials, a net destruction of jobs takes place over the period. We observe both job creation and job destruction in every sector. This shows that the heterogeneity regarding employment decisions that we observe for the manufacturing industry, is still apparent even after disaggregating at narrowly defined industries. The same result has been found for some other countries (see Davis and Haltiwanger (1992), Konings (1995) and Greenan and Guellec (1997) among others). Job creation ranges from 0.8 percent in iron steel and metal to 6.8 percent

3 Spanish economy experienced a slowdown that was quite pronounced in the manufacturing sector. The gross value added in the manufacturing sector rose by a modest 0.7 percent in 1996 as compared to the 4.8 percent registered in 1995. 

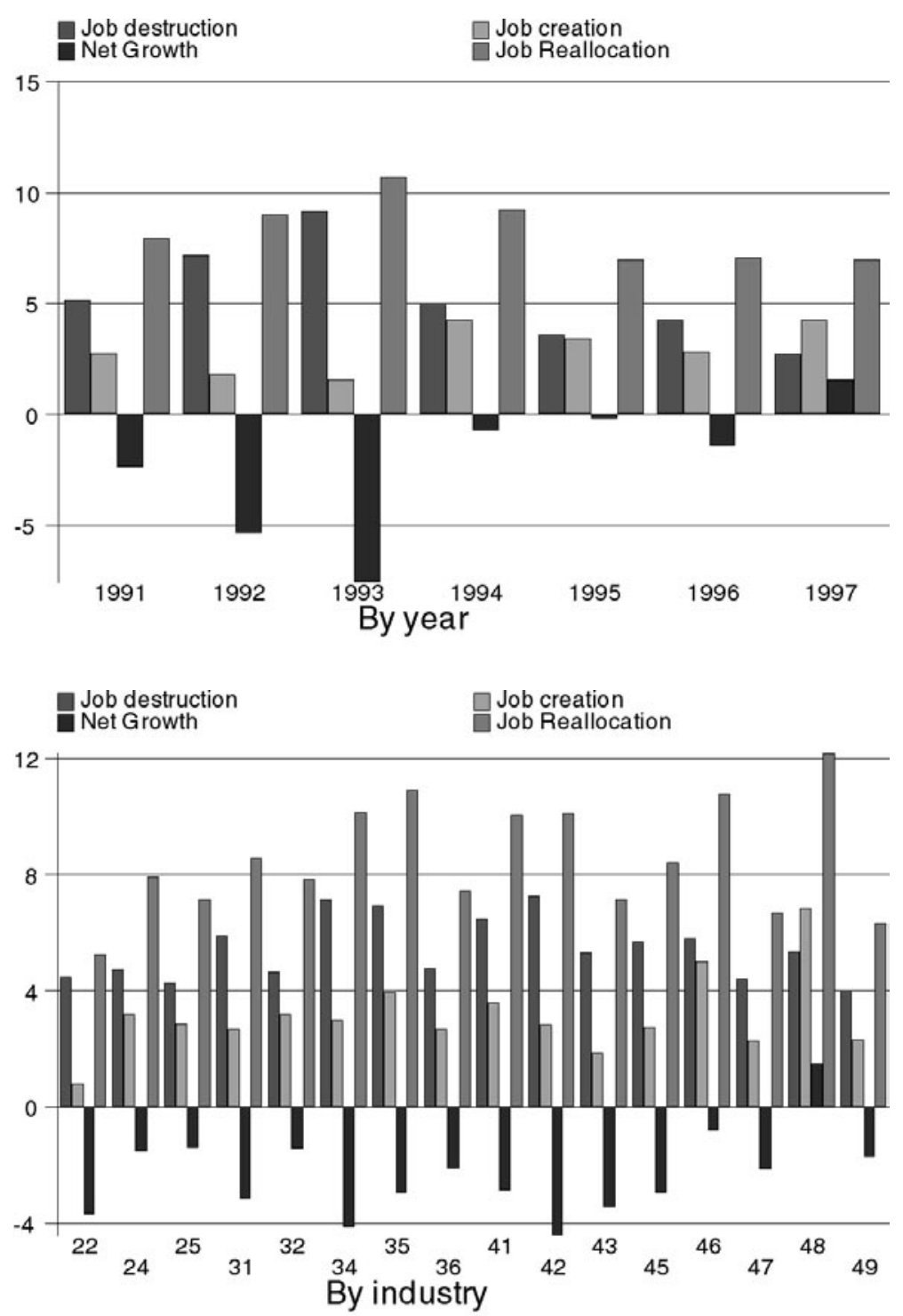

Figure 2 : Job creation and destruction

in plastic materials; job destruction from 4.0 percent in other non-basic industries to 7.3 percent in food, tobacco and drinks; and job reallocation varies from 5.3 percent in iron steel and metal to 13.0 percent in office machinery.

In figure 3, we present job creation, job destruction, net employment growth, and job reallocation rates by different firm characteristics : size, age, market demand conditions and innovation activity. Size refers to average em- 
ployment over the period. The categories for size are : small (0-25 workers), medium (26-150), and large (more than 150 workers). Both job creation and destruction rates decrease with firm size, which is reflected in a declining pattern of job reallocation with size. This result was also found for other countries (See Davis and Haltiwanger (1992), and Greenan and Guellec (1997) among others). However, while the decrease of job creation with size is quite important, the decrease of job destruction is rather moderate and the net effect is that large firms destroy a larger proportion of jobs. This result is at odds with the findings for the US by Davis, Haltiwanger and Schuh (1996) and resembles the evidence for France presented in Greenan and Guellec (1997). The relationship between firms' age and job creation and destruction rates is similar to the empirical evidence for other countries (see Davies and Haltiwanger (1992) for the US, and Blanchflower and Burgess (1996) for the UK, among others). Job creation decreases sharply with age, while the effect of age on job destruction is less obvious. The net effect is that older firms destroy a larger proportion of jobs. Regarding job reallocation, we can see a clear declining pattern with age.

The left-lower panel of figure 3 shows job creation and destruction rates by market demand conditions. The ESEE survey asks companies whether the main market where the firms are operating is in recession, stable or booming. This variable is, therefore, a proxy for negative or positive demand shocks which are specific to the main market where the firm operates. The graph indicates that firms in contracting markets have a very low rate of job creation and a very high rate of job destruction as compared to firms in expanding markets. These results show a strong dependence of firms' employment decisions on market conditions. Finally, in the right-lower panel of figure 3 , we present the average job creation and destruction rate for innovative and non-innovative firms. A firm is classified as innovative if it produces a process innovation in at least one third of the years; according to this definition, 291 firms are innovative and 974 are non-innovative. We can see that innovative firms have lower rates of job creation and destruction, and although the net growth rate is negative for both types of firms, it is lower in absolute value for innovative firms. This result confirms previous evidence of a positive relationship between innovation and employment (see Doms, Dunne and Roberts (1995) and Van Reenen (1997)).

In figures 4 and 5 we further explore the effect of innovation on job creation and destruction rates. In figure 4, we plot job creation and destruction rates by year for innovative and non-innovative firms. Whereas both innovative and non-innovative firms have a similar pattern of job creation and destruction during the recession period, innovative firms have a lower destruction rate in the recovery period. Hence, the net employment growth during those years is higher for innovative than for non-innovative firms. It is worth mentioning that the job reallocation rate exhibits a countercyclical pattern both for innovative and non-innovative firms. In figure 5 we present job creation and destruction rates by size for innovative and non-innovative firms. For all size categories, job creation rates are slightly 


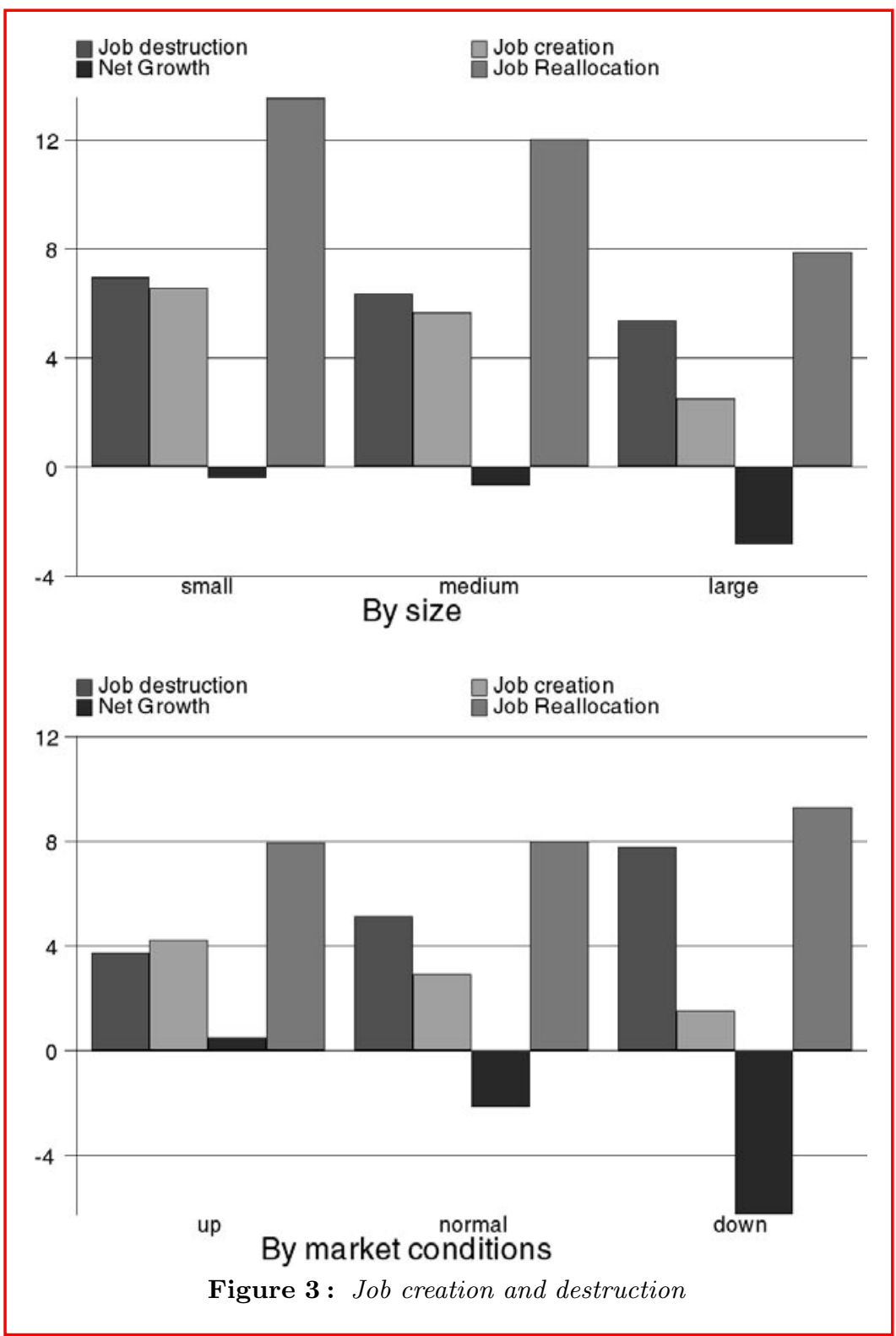

higher for innovative firms, while job destruction rates are higher for noninnovative firms. The net figures show that innovative firms of small and medium size are creating jobs while non-innovative firms are on average destroying employment ${ }^{4}$. Reallocation rates decline with size both for inno-

4 We have also computed job creation and destruction rates by sector, age and market demand conditions for innovative and non-innovative firms. However, these numbers do not add any interesting new evidence and therefore we do not present them in the paper. 


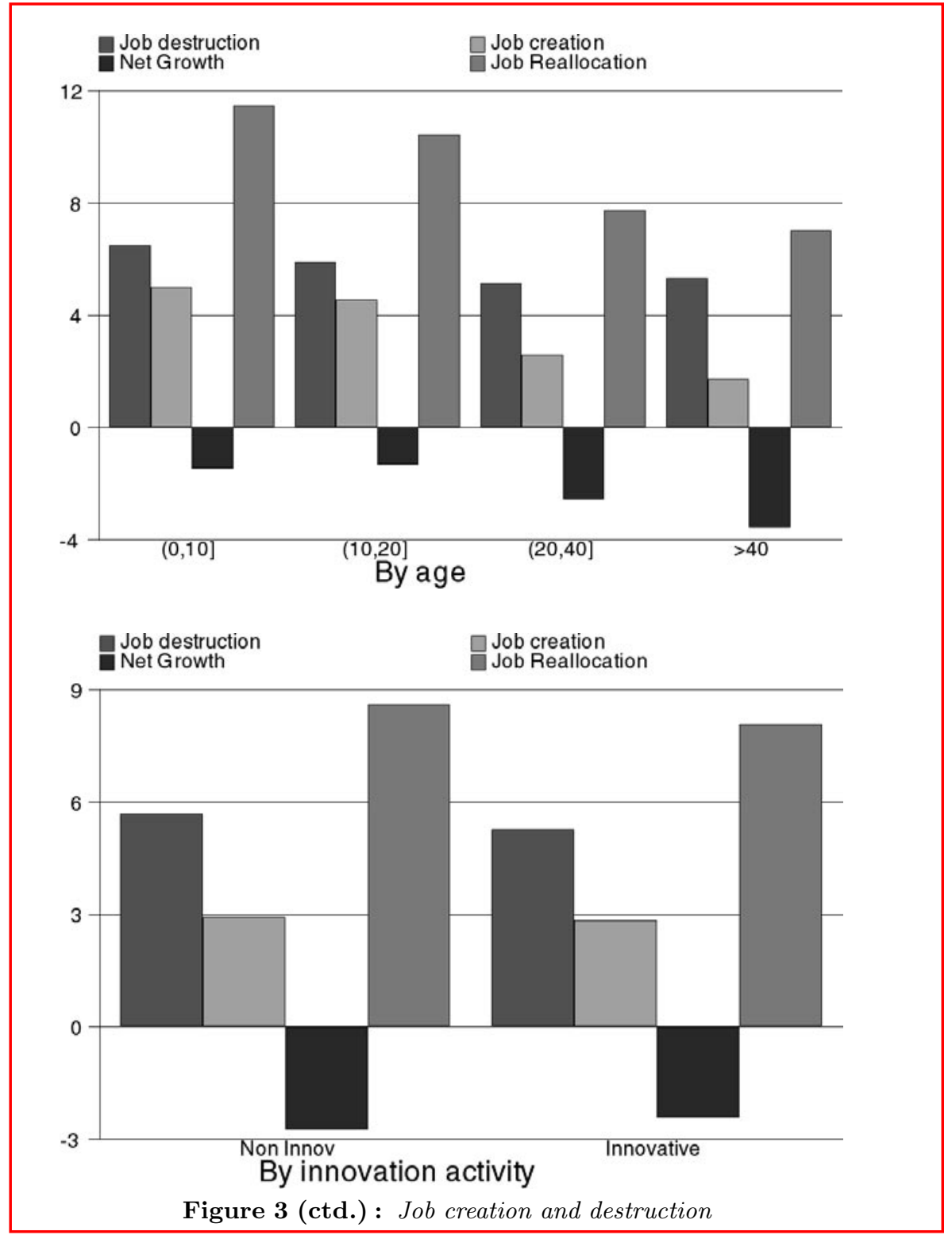

vative and non-innovative firms, but they are slightly lower for innovative firms.

The descriptive evidence in this section sheds some light on the effect of innovation on job creation and destruction. However, our results are not conclusive, in the sense that we can only capture bivariate correlations, which at most can be disaggregated accordingly to some qualitative factors, such as industry, size, or age. Leaving aside some exceptions, like Blanchflo- 

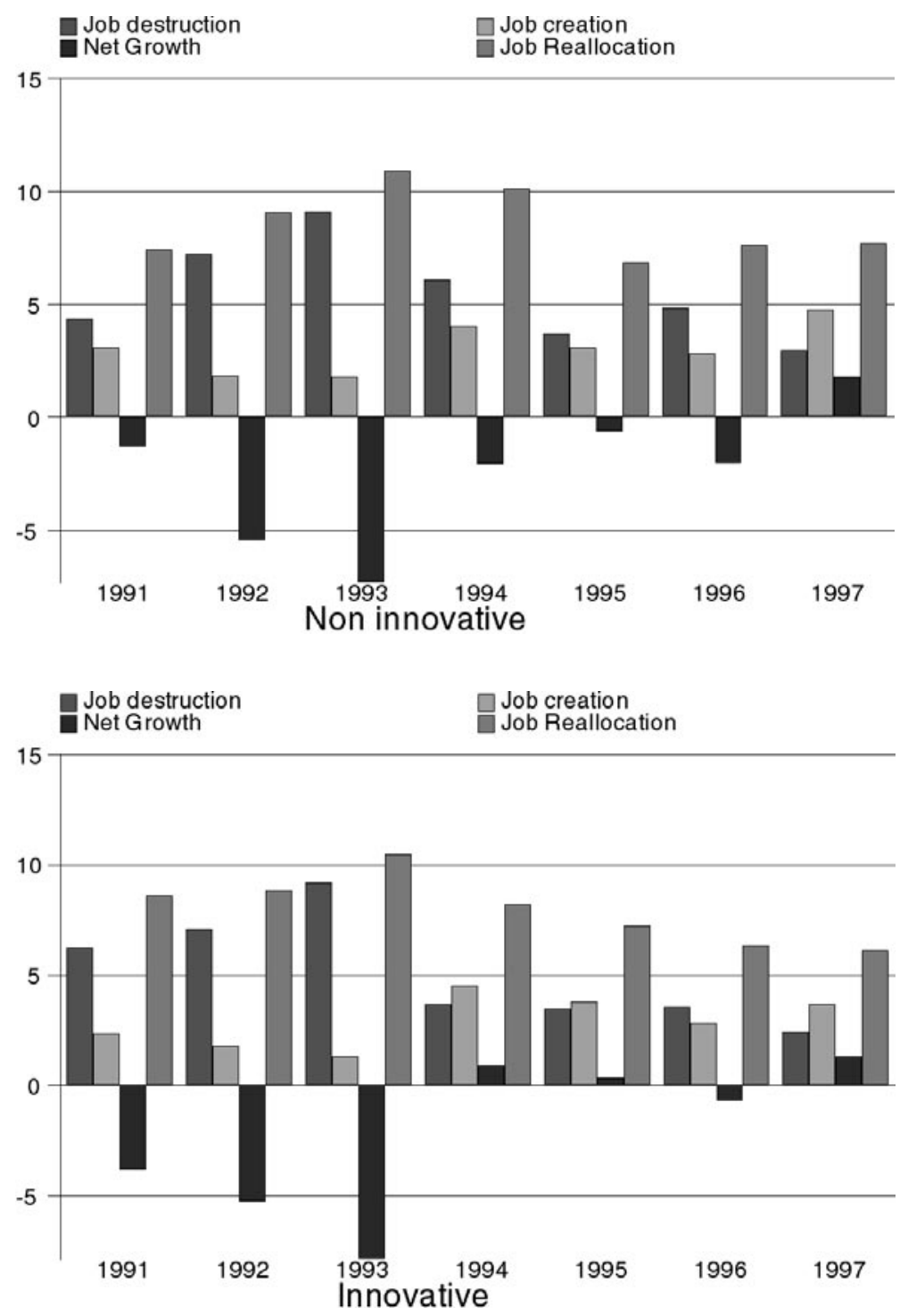

Figure $4:$ Job creation and destruction by year and innovation status

wer and Burgess (1996), most of the empirical contributions on job creation and job destruction restrict the analysis to simple correlations, tabulated by firms' characteristics. Our next step will be to evaluate the effect of innovation on job creation and job destruction in a multivariate context, where such effect is measured conditioning on other determining variables. 


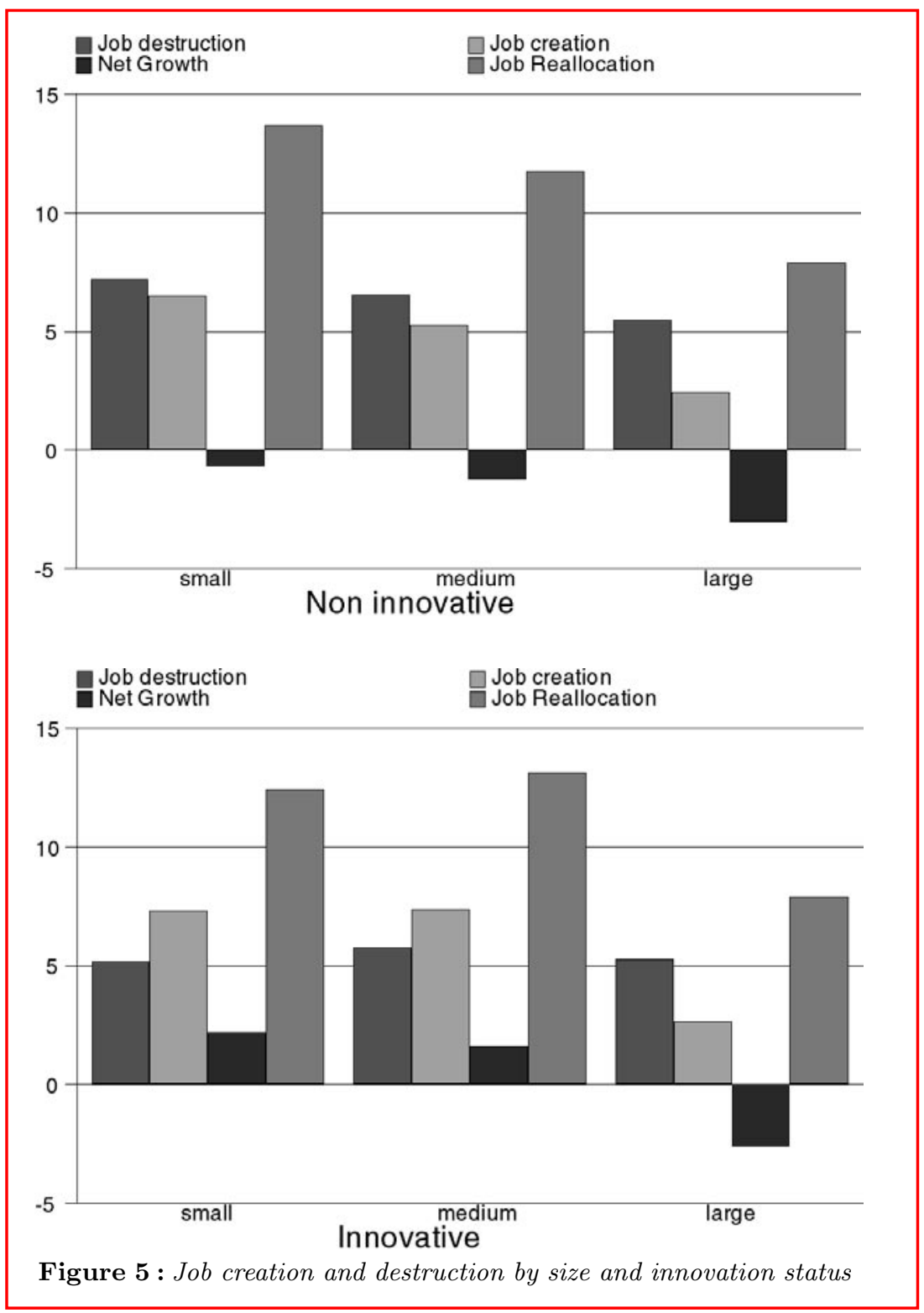

\section{Estimating the effect of innovation}

\subsection{Econometric approach}

We are primarily concerned with evaluating the effect of innovation on job creation and job destruction, controlling for further conditioning variables. 
However, we are aware that these conditioning variables can affect job creation and job destruction very differently. For this reason, we are interested in allowing the coefficients of the conditioning variables to differ for job creation and destruction. Nonetheless, the allocation of observations of each firm in each year among job creation and job destruction is non random, as it depends on the sign of the net employment change, which is clearly endogenous.

In fact, according to their net employment growth, we will observe that firms endogenously choose any of three different states : job creation, job destruction, and inaction. What makes a particular firm be in any of these three states in a particular year depends on whether its marginal intertemporal profit is greater than in the other two states, and therefore it cannot be attributed to purely random reasons. Consequently, if we consider job creation (destruction) determinants using those observations for which job creation (destruction) happens, we must take into account sample selection bias in order to get consistent estimates of the parameters. Firms creating employment in a given year might differ from those with zero or negative employment creation because of reasons unobservable to the analyst that bias the comparison of the estimated effects. We will use a slight modification of the Heckman's (1979) two-step approach so as to correct for sample selection bias.

To see this, we can consider three latent variables for which we have the following equations :

$$
\begin{array}{cl}
y_{1 i}^{*}=x_{i}^{\prime} \beta_{1}+u_{1 i} & \text { (Job Creation Equation) } \\
y_{2 i}^{*}=x_{i}^{\prime} \beta_{2}+u_{2 i} & \text { (Job Destruction Equation) } \\
I_{i}^{*}=z_{i}^{\prime} \gamma+\varepsilon_{i} & \text { (Self-Selection Equation) }
\end{array}
$$

and defining the vector $v_{i}=\left(u_{1 i}, u_{2 i}, \varepsilon_{i}\right)^{\prime}$ containing the unobservable disturbance terms, and $w_{i}$ as the vector containing all the conditioning variables included in $x_{i}$ and $z_{i}$, we assume that

$$
v_{i} \mid w_{i} \sim N(\mathbf{0}, \boldsymbol{\Sigma})
$$

where the outer-diagonal elements of the conditional variance-covariance matrix $\boldsymbol{\Sigma}, E\left(u_{1 i} u_{2 i} \mid w_{i}\right)=\sigma_{12}, E\left(u_{j i} \varepsilon_{i} \mid w_{i}\right)=\sigma_{j \varepsilon}, j=1,2$, are allowed to be nonzero.

However, neither $y_{1 i}^{*}$ nor $y_{2 i}^{*}$ are fully observed. Instead, we observe $y_{i}$ according to the following rule:

$$
y_{i}= \begin{cases}y_{1 i}^{*} & \text { if } I_{i}^{*}>\mu^{+} \\ 0 & \text { if } \mu^{-} \leqslant I_{i}^{*} \leqslant \mu^{+} \\ y_{2 i}^{*} & \text { if } I_{i}^{*}<\mu^{-}\end{cases}
$$

Furthermore, $I_{i}^{*}$ is not fully observed : instead, we just observe its sign,

$$
I_{i}=\left\{\begin{aligned}
1 & \text { if } I_{i}^{*}>\mu^{+} \\
0 & \text { if } \mu^{-} \leqslant I_{i}^{*} \leqslant \mu^{+} \\
-1 & \text { if } I_{i}^{*}<\mu^{-}
\end{aligned}\right.
$$


We can thus write the expectation of $y_{i}$, conditional on the observables, for job creation as

$E\left(y_{i} \mid w_{i}, I_{i}>\mu^{+}\right)=x_{i}^{\prime} \beta_{1}+E\left(u_{1 i} \mid w_{i}, I_{i}>\mu^{+}\right)=x_{i}^{\prime} \beta_{1}+\frac{\sigma_{1 \varepsilon}}{\sigma_{\varepsilon}} \lambda\left(\frac{\mu^{+}-z_{i}^{\prime} \gamma}{\sigma_{\varepsilon}}\right)$

where $\sigma_{\varepsilon}^{2}=E\left(\varepsilon_{i}^{2}\left\lfloor x_{i}, z_{i}\right)\right.$, and $\lambda(v)=\phi(v) /[1-\Phi(v)]$ is the inverse of the Mills' ratio, $\phi(v)$ and $\Phi(v)$ being the density and the cumulative function of the standard normal distribution. Analogously, for job destruction we have that

$E\left(y_{i} \mid w_{i}, I_{i}<\mu^{-}\right)=x_{i}^{\prime} \beta_{2}+E\left(u_{2 i} \mid w_{i}, I_{i}<\mu^{-}\right)=x_{i}^{\prime} \beta_{2}-\frac{\sigma_{2 \varepsilon}}{\sigma_{\varepsilon}} \lambda^{*}\left(\frac{\mu^{-}-z_{i}^{\prime} \gamma}{\sigma_{\varepsilon}}\right)$

where $\lambda^{*}(v)=\phi(v) / \Phi(v)$ is the complement of the Mills' ratio. Therefore, expectations for job creation and job destruction include an additional unobservable term that reflects the sample selection bias. Notice that the situation under which both $\sigma_{1 \varepsilon}$ and $\sigma_{2 \varepsilon}$ are different from zero reflects the endogeneity of the selection. Under such circumstances, it is straightforward to verify that failing to account for sample selection would bias the parameter estimates. However, this term can be consistently estimated for each observation using an ordered probit for $I_{i}$.

In the estimation of the parameters of interest, we proceed in two stages. In the first stage we estimate the parameters needed to predict the values of $\lambda(\cdot)$ and $\lambda^{*}(\cdot)$ for each observation from an ordered probit model of net employment changes, with three discrete outcomes : job destruction, inaction and job creation. In the second stage we estimate the parameters for job creation and job destruction by means of augmented regressions based on (12) and (13), where we substitute the unobservable terms $\lambda(\cdot)$ and $\lambda^{*}(\cdot)$ for the predicted values obtained in the first stage from the ordered probit estimates. This approach has also been applied by Frazis (1993) in order to control for selection bias in the estimation of the college degree effect. ${ }^{5}$

\subsection{Estimation results}

Our set of innovation variables comprise qualitative time-invariant indicators about innovation status based on measures of innovation generated by the firms, and a continuous variable based on inputs used by the firm to produce innovations. Regarding qualitative variables, as indicator on whether the firm is innovative, we consider whether the firm has introduced

5 It would also be possible to derive the expectation of $y_{i}$ for the full population and consider the joint estimation of $\beta_{1}$ and $\beta_{2}$ for the whole sample. However, the fact that the estimated probabilities of creating or destructing employment interact nonlinearly with the $x_{i}$ 's makes the estimates much more imprecise. Evidence from our data, and further evidence based on Monte Carlo simulations, confirm that the results based on subsample estimates are much more precise than the ones for the whole sample. 
process innovations in at least one third of the years in the sample period. Although we have also considered additional measures of innovation status, such as indicators based on product innovations and on registered patents, their effects have been found non-significant so that we do not report the results here. With respect to continuous variables of innovation, we have also included the firm's technological effort, defined as the percentage in its total sales of R\&D expenditure and technology imports.

In the set of conditioning variables we have also included the change in the logarithm of intermediate inputs as a proxy for idiosyncratic shocks, the lagged logarithm of the employment level to control for firm size, and the logarithm of the lagged capital-labour ratio and the percentage of blue collar employment to control for input composition. The change in the logarithm of intermediate inputs has also been interacted with the indicator based on process innovations in order to capture differences in the impact of idiosyncratic shocks according to the innovation status of the firm. In addition, we include dummies for the age of the firm, as well as two dummies that indicate if the market where the firm operates is growing or decreasing, respectively. We have also included in all the estimations time dummies so as to control for aggregate shocks, and industry dummies to control for this source of heterogeneity among firms.

The ordered probit estimates are shown in Table 1. Although these estimates only have an auxiliary role in our analysis, some interesting patterns arise. The change in intermediate inputs shows a positive and significant coefficient, as expected, pointing out that positive firm-specific shocks tend to increase employment. In addition, the variables indicating expanding and contracting markets are significant and show the expected signs. The dummies for firm age point out, other things being equal, a negative and nonlinear effect of age on employment growth. A positive effect of the capital-labour ratio is also found, and a negative though small effect of the proportion of blue collar in total firm's employment. The logarithm of lagged employment has a negative and significant effect, which we interpret as a negative effect of firm's size on employment growth. The variable on whether the firm has introduced process innovations has a positive and significant effect. The positive effect of technological effort on employment growth is also remarkable. Another interesting result is that the effect of idiosyncratic shocks, measured by the change in intermediate inputs, is greater for those firms which have introduced process innovations, which we have captured by means of the variable which interacts the change in intermediate inputs with the qualitative indicator for process innovations. Hence, it appears that innovative firms are more prompted to create (destroy) jobs if the firm faces positive (negative) idiosyncratic shocks.

In Table 2, we present the estimates for job creation and job destruction, conditional on positive and negative employment changes, respectively. In the first and third columns we report the estimates ignoring selectivity bias, whereas our estimates in the second and fourth columns have taken proper account of sample selectivity. Regarding the estimates without se- 
Table 2: Job creation and job destruction Ordered probit estimates

\begin{tabular}{lcc}
\hline Process Innovation & 0.0814 & $(0.0395)$ \\
Technological effort & 1.7117 & $(0.7176)$ \\
Intermediate Inputs & 0.4224 & $(0.0464)$ \\
Interm. Inputs*Proc. Innov. & 0.2413 & $(0.1116)$ \\
Ln(N) & -0.1577 & $(0.0136)$ \\
Ln(K/N) & 0.1053 & $(0.0178)$ \\
White Collars & -0.0010 & $(0.0009)$ \\
Age2 & -0.0429 & $(0.0378)$ \\
Age3 & -0.1674 & $(0.0428)$ \\
Age4 & -0.2739 & $(0.0557)$ \\
Expanding Market & 0.2004 & $(0.0366)$ \\
Contracting Market & -0.2991 & $(0.0370)$ \\
\hline No. Observations & 6923 & \\
Likelihood ratio test (p-value) & 877.42 & $(0.0000)$ \\
\hline
\end{tabular}

The dependent variable takes on three discrete values that denote destruction, inaction and creation, respectively.

Description of the variables

Process Innovation
Dummy variable indicating whether the firm has introduced process
innovations in at least one third of the years in the sample period
Technological effort
Percentage in firm total sales of R\&D expenditure and technology imports
Intermediate Inputs
Change in the logarithm of intermediate inputs
Interm. Inputs*Proc. Innov. $\quad$ interacted with the dummy for proccess innovations
Logarithm of employment lagged one period
Ln(N)
Logarithm of the capital/labor ratio lagged one period
An(K/N)
Age 3 ( $21-40$ years), Age 4 (more than 40 years)
Proportion of white collars over employment


Table 3 : Job creation and job destruction

\begin{tabular}{|c|c|c|c|c|}
\hline \multirow[b]{2}{*}{ Process Innovation } & \multicolumn{2}{|c|}{ Job creation } & \multicolumn{2}{|c|}{ Job destruction } \\
\hline & $\begin{array}{c}0.0123 \\
(0.0066)\end{array}$ & $\begin{array}{c}0.0488 \\
(0.0146)\end{array}$ & $\begin{array}{l}-0.0115 \\
(0.0055)\end{array}$ & $\begin{array}{l}-0.0393 \\
(0.0089)\end{array}$ \\
\hline Technological effort & $\begin{array}{c}0.0644 \\
(0.1628)\end{array}$ & $\begin{array}{c}0.8497 \\
(0.3064)\end{array}$ & $\begin{array}{l}-0.0726 \\
(0.1026)\end{array}$ & $\begin{array}{l}-0.6089 \\
(0.1785)\end{array}$ \\
\hline Intermediate Inputs & $\begin{array}{c}0.0714 \\
(0.0140)\end{array}$ & $\begin{array}{c}0.2634 \\
(0.0665)\end{array}$ & $\begin{array}{l}-0.0417 \\
(0.0163)\end{array}$ & $\begin{array}{l}-0.1728 \\
(0.0349)\end{array}$ \\
\hline Interm. Inputs*Proc. Innov. & $\begin{array}{l}-0.0511 \\
(0.0215)\end{array}$ & $\begin{array}{c}0.0496 \\
(0.0349)\end{array}$ & $\begin{array}{l}-0.0164 \\
(0.0250)\end{array}$ & $\begin{array}{l}-0.0813 \\
(0.0313)\end{array}$ \\
\hline $\operatorname{Ln}(\mathrm{N})$ & $\begin{array}{l}-0.0389 \\
(0.0031)\end{array}$ & $\begin{array}{l}-0.1111 \\
(0.0241)\end{array}$ & $\begin{array}{l}-0.0153 \\
(0.0024)\end{array}$ & $\begin{array}{c}0.0340 \\
(0.0123)\end{array}$ \\
\hline $\operatorname{Ln}(\mathrm{K} / \mathrm{N})$ & $\begin{array}{c}0.0193 \\
(0.0041)\end{array}$ & $\begin{array}{c}0.0666 \\
(0.0168)\end{array}$ & $\begin{array}{l}-0.0172 \\
(0.0036)\end{array}$ & $\begin{array}{l}-0.0501 \\
(0.0086)\end{array}$ \\
\hline White Collars & $\begin{array}{l}-0.0002 \\
(0.0002)\end{array}$ & $\begin{array}{l}-0.0006 \\
(0.0002)\end{array}$ & $\begin{array}{l}-0.0004 \\
(0.0002)\end{array}$ & $\begin{array}{l}-0.0001 \\
(0.0002)\end{array}$ \\
\hline Age2 & $\begin{array}{l}-0.0264 \\
(0.0074)\end{array}$ & $\begin{array}{l}-0.0437 \\
(0.0098)\end{array}$ & $\begin{array}{l}-0.0279 \\
(0.0086)\end{array}$ & $\begin{array}{l}-0.0126 \\
(0.0094)\end{array}$ \\
\hline Age3 & $\begin{array}{l}-0.0390 \\
(0.0069)\end{array}$ & $\begin{array}{l}-0.1127 \\
(0.0243)\end{array}$ & $\begin{array}{l}-0.0403 \\
(0.0078)\end{array}$ & $\begin{array}{c}0.0156 \\
(0.0155)\end{array}$ \\
\hline Age4 & $\begin{array}{l}-0.0275 \\
(0.0091)\end{array}$ & $\begin{array}{l}-0.1528 \\
(0.0404)\end{array}$ & $\begin{array}{l}-0.0303 \\
(0.0087)\end{array}$ & $\begin{array}{c}0.0559 \\
(0.0235)\end{array}$ \\
\hline Expanding Market & $\begin{array}{c}0.0085 \\
(0.0058)\end{array}$ & $\begin{array}{c}0.0980 \\
(0.0282)\end{array}$ & $\begin{array}{c}0.0018 \\
(0.0071)\end{array}$ & $\begin{array}{l}-0.0671 \\
(0.0174)\end{array}$ \\
\hline Contracting Market & $\begin{array}{c}0.0021 \\
(0.0087)\end{array}$ & $\begin{array}{l}-0.1453 \\
(0.0482)\end{array}$ & $\begin{array}{c}0.0178 \\
(0.0070)\end{array}$ & $\begin{array}{c}0.1074 \\
(0.0233)\end{array}$ \\
\hline Selectivity term* & & $\begin{array}{c}0.6830 \\
(0.2133) \\
\end{array}$ & & $\begin{array}{c}0.5177 \\
(0.1280)\end{array}$ \\
\hline No. Observations & 2647 & 2647 & 3241 & 3241 \\
\hline $\begin{array}{l}\text { Wald tests of joint } \\
\text { significance (p-value) }\end{array}$ & $465.1(0.000)$ & $505.8(0.000)$ & $475.2(0.000)$ & $490.8(0.000)$ \\
\hline Wald tests (p-value) & & & & \\
\hline Age dummies & $32.6(0.000)$ & $31.3(0.000)$ & $27.0(0.000)$ & $22.2(0.000)$ \\
\hline Time dummies & $12.4(0.053)$ & $18.7(0.005)$ & $33.6(0.000)$ & $44.9(0.000)$ \\
\hline Industry dummies & $91.2(0.000)$ & $93.9(0.000)$ & $52.8(0.000)$ & $68.3(0.000)$ \\
\hline
\end{tabular}

lectivity bias correction, we find that several variables are non significant, and some of them have wrong signs. The first noticeable result from the estimates that control for sample selectivity is that the selectivity correction terms are strongly significant. Furthermore, most variables are significant. In particular, the sets of time and the set of industry dummies were found to be jointly significant. In table 3 , we present Wald tests for equality of 
Table 4: Tests for equality of coefficients in job creation and job destruction equations

\begin{tabular}{lc}
\hline & test (pvalue) \\
Process Innovation & $0.3061(0.5801)$ \\
Technological effort & $0.4607(0.4973)$ \\
Intermediate Inputs & $1.4534(0.2280)$ \\
Interm. Inputs*Proc. Innov. & $0.4560(0.4995)$ \\
$\mathrm{Ln}(\mathrm{N})$ & $8.1544(0.0043)$ \\
$\mathrm{Ln}(\mathrm{K} / \mathrm{N})$ & $0.7573(0.3842)$ \\
White Collars & $6.9935(0.0082)$ \\
Age dummies & $32.2537(0.0000)$ \\
Expanding/Contracting Markets & $1.0356(0.5958)$ \\
\hline
\end{tabular}

coefficients in the job creation and job destruction equations, and we find evidence of asymmetries in some estimated effects on job creation and job destruction ${ }^{6}$.

Concerning shocks, we find that idiosyncratic shocks (captured by the rate of change in intermediate inputs) have a positive effect on job creation, and a negative effect in job destruction. The variables controlling for the state of demand in the main market where the firm operates (whether the market is expanding or contracting) also have the expected signs. Although the incidence of market conditions appears to be higher for job creation than for job destruction, the difference is not statistically significant.

We also find a positive effect of the capital-labour ratio on employment growth, and a negative but small effect of the proportion of blue collar labour. Moreover, lagged employment has a negative effect on job creation and a positive effect on job destruction, yet the magnitude (in absolute value) is significantly smaller for job destruction. This result might be interpreted as a negative effect of size on employment growth, so that smaller firms tend to create more (and to destroy less) employment than large firms.

The firm's maturity, measured by means of three dummy variables on age, has a negative effect on employment growth, yet again the effect appears to be significantly greater for job creation than for job destruction (the hypothesis of equality of the coefficients on the age dummies is rejected at any significance level). According to the Wald test, the age variables were jointly significant in both equations.

Concerning the innovation variables, the importance of controlling for sample selection bias is very apparent, since we observe dramatic changes in the size and precision of the estimated coefficients. When sample selection bias is accounted for, all the innovation variables turn out to be strongly significant. The qualitative indicator of process innovations shows a positive effect on employment growth. The estimations point out that innovative

${ }^{6}$ Equality of coefficients means the same value with opposite sign. 
firms create more employment (and destroy less employment) than noninnovative firms. Consequently, on average, innovative firms create more net jobs than non-innovative ones.

Another interesting result concerns the interaction between the change in the logarithm of intermediate inputs and the qualitative indicator of introducing process innovations. We also find that whereas the effect of idiosyncratic shocks on job creation is not significantly different for innovative and non-innovative firms, their effect on job destruction is particularly stronger for innovative firms.

In addition to the qualitative variables for innovation, we have also included the logarithm of firm's technological effort, which is a time-varying continuous variable. The estimates shows a strongly positive effect of technological effort on net employment creation. The absolute values of the estimated coefficients are not significantly different for job creation and job destruction, so that we do not find evidence of asymmetric effects of innovation variables on job creation and destruction.

Finally, we have evaluated the robustness of the results to the definitions of the variables used in the estimations. ${ }^{7}$ First, to account for the potential bias due to endogeneity of the employers' claims about the state of their main market, we have alternatively use the median claim of the employers for each industry in the data set, finding similar results. Second, we have used alternative definitions of the innovation indicators by choosing a different cut-off : instead of coding this variable as 1 if the firm generates process innovations in at least one third of the sample years, we have redefined it on a year-by-year basis, coded 1 if the firm did generate an innovation in the previous year and 0 otherwise. Third, we have used the information on patents and product innovations to define alternative definitions of innovation indicators, yet the main effect is imputable to process innovations and the main results did not change.

\section{Conclusions}

The main concern of this paper has been to study the impact of firms' innovation activity on job creation and job destruction. Innovation activity appears to be particularly important since the 1990s because of its potential complementarity with IT, which has lived a widespread adoption during such period. In order to do this, we have estimated reduced form equations for job creation and job destruction, for which we have taken account of the sample selection bias induced by the endogeneity of firms' decisions on whether to hire or to lay off.

The preliminary evidence confirms the large heterogeneity of firmlevel employment changes even for narrowly defined industries, which had

7 These additional estimations have not been included for the sake of brevity, but are available upon request. 
been previously found for other countries. In addition, the shape of job creation and job destruction also resembles the findings from previous studies, in particular, about a positive relationship between innovation and employment.

Our main findings, based on our multivariate analysis for job creation and job destruction, can be summarized as follows. First, innovative firms tend to create more - and to destroy less - employment than non innovative firms, this effect being more important for the innovation measure based on process innovations. Second, technological effort has a strongly positive effect on net employment creation. Finally, we find that job destruction is more sensitive to idiosyncratic shocks in the case of innovative firms.

Our results provide evidence supporting the fact that innovation is one of the driving forces behind the net creation of jobs in Spanish manufacturing, and that this effect is increasing with the degree of technological effort. One problem with our analysis is that the estimates only capture partial correlations, which do not have further interpretation due to the lack of a model that might establish how parameters depend on the technology and adjustment cost structure of firms. The role of innovation in the dynamics of job creation and job destruction appears as a promising topic for future research.

\section{References}

Aguirregabiria, V. and C. Alonso-Borrego (2001), "Occupational structure, technological innovation, and reorganization of production", Labour Economics, 8, 43-73.

Blanchflower, D.G. and S.M. Burgess (1996), "Job Creation and Job Destruction in Great Britain in the 1980s", Industrial and Labor Relations Review, 50, 17-38.

Brynjolfsson , E. and L.M. Hitt (2000), "Beyond Computation : Information Technology, Organizational Transformation and Business Performance", Journal of Economic Perspectives, 14, 23-48.

Davis, S. and J. Haltiwanger (1992), "Gross Job Creation, Gross Job Destruction, and Employment Reallocation", Quarterly Journal of Economics 107, 819-863.

Davis, S. and J. Haltiwanger (1999?), "Gross Job Flows", Handbook of Labor Economics, Vol. 3 and 4

Davis, S., J. Haltiwanger and S. Schuh (1996), "Small Business and Job Creation : Dissecting the Myth and Reassessing the Facts", Small Business Economics, 8, 297-315. 
Díaz-Moreno, C. and J.E. Galdón-Sánchez (2000), "Job Creation, Job Destruction and the Dynamics of Spanish Firms", Investigaciones Económicas, 24, 545-561.

Dolado, J.J. and R. Gómez (1995), "Creación y Destrucción de Empleo en el Sector Privado Manufacturero Español: Un Análisis Descriptivo", Investigaciones Económicas, 19, 371-393.

Doms, M., T. Dunne and M. J. Roberts (1995), "The Role of Technology Use in the Survival and Growth of Manufacturing Plants", International Journal of Industrial Organization, 13, 523-542.

Frazis, H. (1993), "Selection Bias and the Degree Effect", Journal of Human Resources, 28, 538-554.

Greenan, N. and D. Guellec (1997), Technological Innovation and Employment Reallocation, mimeo.

Heckman, J.J. (1979), "Sample Selection Bias as an Specification Error", Econometrica, 47, 153-161.

Konings, J. (1995), "Job Creation and Job Destruction in the UK Manufacturing Sector", Oxford Bulletin of Economic and Statistics, 57, 5-24.

Lehr, B. and F. Lichtenberg (2000), "Information Technology and Its Impact on Productivity : Firm-Level Evidence from Government and Private Data Sources", Canadian Journal of Economics, 32, 335-362.

Meghir, C., A. Ryan and J. Van Reenen (1996), "Job Creation, Technological Innovation and Adjustment costs : Evidence from a Panel of British Firms", Annales d'Economie et de Statistique, 41/42, 255-274.

Ruano, S. (2000), "Creación y Destrucción Bruta de Empleo en las Empresas Industriales Españolas", Investigaciones Económicas, 24, 563-584.

Van Reenen J. (1997), "Employment and Technological Innovation : Evidence from U.K. Manufacturing Firms", Journal of Labor Economics, $15,255-284$.

Visco, I. (2000), "The New Economy : Fact or Fiction?", OECD Observer, June 2000 . 